Вісник Дніпропетровського університету. Серія: геологія, географія. 2016. 24 (1), 90-97.

Vìsnik Dnìpropetrovs'kogo unìversitetu. Seriâ geologîâ, geographìâ

Dnipropetrovsk University Bulletin. Series geology, geography. 2016, 24 (1), 90-97.

doi: $10.15421 / 111613$

http://geology-dnu.dp.ua

УДК 911.3

\title{
Аналіз розвитку наукових підходів до типології та класифікації натуральних лісових ландшафтів
}

\author{
М. М. Мельнійчук, В. Ю. Чабанчук \\ Східноєвропейський національний університет імені Лесі Украйнки, Луцььк, Україна, \\ e-mail: mel.mm@mail.ru; stela@email.ua
}

\begin{abstract}
Проаналізовано історію розвитку досліджень лісової типології від її зародження до сучасного етапу. Виявлено відмінності між двома основними напрямами у типології лісу: екологічному і ботанічному. Встановлено зв'язки між дослідженнями різних учених у різні історичні періоди, виявлено недоліки та переваги кожного з основних підходів до визначення типу лісу. На основі аналізу праць Г. Ф. Морозова, А. А. Крюденера, С. В. Алексєєва, П. П. Кожевнікова, Д. В. Воробйова, П. С. Погребняка, А. К. Каяндера, В. М. Сукачова та інших учених зроблено висновок, що лісотипологічна наука зазнала свого розквіту у XIX столітті. На сучасному етапі варто зазначити деякий занепад цього напряму досліджень, оскільки лише деякі науковці продовжують вивчення типів лісу, зокрема, М. М. Вересін, В. І. Білоус, М. А. Голубець та ін., але характер їхніх праць або регіональний або вибірковий (наприклад, М. М. Вересін досліджував лише діброви). Багато праць присвячено антропогенним лісовим ландшафтам, проте саме в умовах антропогенізації актуальності набуває необхдність глибшого вивчення застосування типологічного вчення для раціонального використання лісових ресурсів та збереження осередків натуральних лісових ландшафтів.
\end{abstract}

Ключові слова: лісова типологія, тип лісу, тип насадження, едафічна сітка, фіточенологія

\section{Analysis of scientific approaches to the typology and classification of natural forest landscape}

\author{
M. M. Melnichuk, V. Yu. Chabanchuk \\ Lesya Ukrainka Eastern European National University, Lutsk, Ukraine, e-mail: mel.mm@mail.ru; stela@email.ua
}

This article analyzes the process of formation of modern forest typology in Ukraine. The study deals with the different stages of the research forest typology science from its beginnings to the modern stage. We explored the works of scientists representatives of two main directions in the forests typology, such as botanical and ecological. One of them has developed in the north of Russia, where forest landscapes did not suffer from the human impact. This area of forest typology was developed in the works of A. K Kayander, V. M. Sukachov and his students. Another trend appeared in Ukraine, where forests have undergone human activities. This trend has developed in the works of E. V. Alekseev, P. S. Pogrebnyak, D. V. Vorobov and others. As a result, our research presents links between the works of various scientists, its found differences between the main areas of forest typology, their advantages and disadvantages. In a botanical approach forest type identified with plant association. On the other hand, ecological direction of forest typological classification takes into account environmental conditions. Based on the analysis it should be noted that in the XXI century forest typology science is declining. Although it has experienced its heyday in the XIX century, when the theoretical foundations of the science were formulated. Since only a few scientists continue to study forest types (for example Veresin M. M., Belous V. I., Holubec M. A. and others), their works are narrowly directed and apply only to a particular forest type (for example oak) or a particular region. At present time many scientists have devoted their research to anthropogenic forest landscapes, including Davydchuk V.S., Denysyk G. I., Molchanova A. A. They continue works of Milkov F. M. and focus their attention on the impact of human and economic activities on the forest landscapes. As a result, it should be noted the necessity of restoring and deeper studying of previous experience of forest typology science and its future development. It is necessary to introduce anthropogenic landscapes to forest typology, although pay more attention to natural forest landscapes for the rational use of forest resources and preserving as much as possible the natural habitat of forests and slowing antropohenization.

Keywords: forest typology, forest type, planting type, edaphic grid, phytosociology

Вступ. На сучасному етапі розвитку суспільства все гостріше постає проблема антропогенного впливу на навколишнє середовище, зокрема, і на лісові екосистеми. Впровадження стратегії сталого розвитку у всіх сферах життя і господарювання людини стає надзвичайно актуальним. Таким чином, одним із пріоритетів на майбутнє стає раціональне використання та збереження для наступних поколінь 
природних ресурсів, особливо вичерпних. Одними 3 таких ресурсів є лісові, що зазнають активного знищення та зменшення ареалів поширення, лісистість територій щорічно зменшується, а натуральні лісові ландшафти змінюються антропогенними. В таких умовах актуальності набуває лісотипологічна наука, яка дозволяє пізнати функціональні відмінності між різними типами лісових геосистем, особливостями їх організації та впроваджувати необхідні механізми лісовідновлення та раціонального лісокористування.

Аналіз попередніх досліджень. За останні десятиліття лісотипологічна наука в Україні, що зазнала свого розквіту ще у XIX ст., коли було сформульовано іiі теоретичні основи, занепадає. Лише деякі вчені продовжують вивчення типів лісу (наприклад, М. М. Вересін, В. І. Білоус, М. А. Голубець, Г. І. Денисик, В. С.Давидчук та інші), але їхні праці мають вузько направлений характер, стосуючись лише окремого типу лісу (наприклад, діброви) чи окремого регіону, або спрямовані на дослідження антропогенних лісових ландшафтів. Натуральним лісовим ландшафтам сучасні науковці присвячують мало уваги.

Мета роботи - проаналізувати попередній досвід учених у дослідженні типів лісу, виявити недоліки та переваги різних підходів та сконцентрувати увагу на необхідності подальшого розвитку і вивчення цієї науки для збереження натуральних лісових ландшафтів та запровадження раціонального використання лісових ресурсів.

Виклад основного матеріалу. Лісова типологія - це наука, яка пояснює причини відмінності природних лісів, їх різноманітність, включаючи умови навколишнього середовища та властивості деревних порід.

Перші спроби типології лісів належали лісівникам і ботанікам, тому не враховували взаємодію лісів iз довкіллям, а мали вигляд класифікації лісових насаджень та рослинних угрупувань (Krjudener, 1916). Термін «тип лісу» або «тип насадження» увів в науку наприкінці ХІХ століття Д. М. Кравчинський, хоча серед науковців існує безліч трактувань цього поняття (таблиця 1).

Перші спроби поділити ліси на певні категорії зробили у 90-х роках XIX століття лісівники: Н. К. Генко (Genko, 1902), I. I. Гуторович (Gutorovich, 1908), П. П. Серебреников (Serebrennikov, 1904). Автори використали народні назви, такі як рада, согра, біль, холма, суболоть, бор та ін. у таксаційних описах лісів. На основі таких назв. I. I. Гуторович у 1893 році виділив дев'ять типів лісу.

П. П. Серебреников у 1913 році поділив ліси за деревостаном та за вологістю (Svyrydenko, 2004). Виділяючи типи лісу, почав враховувати лісорослинні умови професор О. Ф. Рудзький (Rudzkij, 1906). У своїй типології він брав до уваги місцеоселення рослин, природні умови, господарське значення лісу. Таким чином, учений поділяє ліси на «відділи» (або «первообрази», «умовні утворення»), наприклад: 1) хвойно-листяний ліс, 2) ялина по раменю, 3) сосна мяндова на сирому грунті, 4) береза чиста та мішана 5) дуб тощо (Kanskyi, 2014).

Почав ураховувати антропогенний вплив на лісові насадження і ввів у науку термін „господарський тип лісів" відомий лісівник Д. М. Кравчинський (Kravchinskij, 1883). Професор-ботанік С. І. Коржинський (Korzhinskij, 1886) в основу своєї лісової типології поклав склад деревостану, кущів, трав'яного і мохового покривів, але недоліком його класифікації було неврахування умов довкілля.

Основоположником вчення про типи лісу вважається Г. Ф. Морозов (Morozov, 1949). Значний внесок у розвиток лісової типології також зробили вчені А. А. Крюденер (Krjudener, 2003), Є. В. Алексєєв (Alekseev, 1927) Г. М. Висоцький (Vysockij, 1960), ідеї яких були розвинуті у дослідженнях П. П. Кожевнікова (Kozhevnykov, 1931), Д. В. Воровйова (Vorobev, 1953) та П. С. Погребняка (Pogrebnjak, 1955). Іншим напрямом у розвитку лісової типології були праці А. К. Каяндера (Kajander, 1933), B. М. Сукачова (Sukachjov, 1972) та його учнів.

У другій половині XX - на початку XXI століття розвитком ландшафтознавчої типології натуральних лісів в Україні займалися М. М. Вересін (Veresin, 1971), В. І. Білоус (Bilous, 1994) та М. А. Голубець (Holubets, 2000).

Г. Ф. Морозов - фундатор вчення про ліс та наукову лісову типологію. Переломним моментом у розвитку типологічного вчення став вихід у «Лесному журнале» 1904 року статті Г. Ф. Морозова «Про типи насаджень та їх значення у лісівництві» (Morozov, 1904). В цій праці вчений розкрив значення і перспективи вивчення лісів у єдності з середовищем ïх існування.

У ранньому періоді своїх досліджень вчений надавав першочергового значення лісорослинним умовам, не враховуючи повною мірою склад порід, бонітет й інші ознаки деревостану. Проте до 1912 року він позбувся таких помилкових поглядів у праці «Вчення про ліс» (Morozov, 1949). В основу своєї лісової типології Г. Ф. Морозов поклав такі чинники: 1) географічне середовище (рельєф, клімат тощо); 2) властивості деревостану; 3) біосоціальні відношення між рослинами та довкіллям; 4) антропогенний вплив; 
Поняття «тип лісу»

\begin{tabular}{|l|l|}
\hline \multicolumn{1}{|c|}{ Джерело (автор) } & \multicolumn{1}{c|}{ Запропоноване визначення } \\
\hline $\begin{array}{l}\text { Сукачов В. М. } \\
\text { Sukachjov, 1972) }\end{array}$ & $\begin{array}{l}\text { «Ділянки лісу, однорідні за складом деревних порід та інших ярусів, рослинністю, фауною, } \\
\text { комплексом лісорослинних умов (кліматичних, грунтових і гідрологічних), за взаєминами } \\
\text { між рослинами і середовищем, за відновними процесами і за напрямками змін у них; за } \\
\text { однакових економічних умов вимагають однорідних лісогосподарських заходів» }\end{array}$ \\
\hline $\begin{array}{l}\text { Морозов Г. Ф. } \\
\text { [Morozov, 1904] }\end{array}$ & «Сукупність насаджень, об’єднаних в одну групу спільністю умов місцезростання» \\
\hline $\begin{array}{l}\text { Колесник Б. П. } \\
\text { Kolesnikov, 1958) }\end{array}$ & $\begin{array}{l}\text { «Сукупність насаджень усіх стадій одного циклу вікових або коротковікових змін, що } \\
\text { ваюуються в межах ділянок території, подібних за положенням і властивостями, і } \\
\text { маюднаковий лісорослинний ефект» }\end{array}$ \\
\hline $\begin{array}{l}\text { Бельгард О. Л. } \\
\text { Веlgard, 1950) }\end{array}$ & $\begin{array}{l}\text { «Сукупність ділянок рослинності, об’єднаних екологічною спільністю едатопу, із загаль- } \\
\text { ним набором життєвих форм рослин, подібних за вимогливістю до трофності та вологості } \\
\text { грунтів» }\end{array}$ \\
\hline $\begin{array}{l}\text { Воробйов Д. В. } \\
\text { (Vorobev, 1953) }\end{array}$ & $\begin{array}{l}\text { «Це сукупність землі, рослинності (домінують дерева та кущі), тварин, мікроорганізмів } \\
\text { та інших компонентів, що у своєму розвитку біологічно взаємопов’язані, впливають один } \\
\text { на одного і на середовище» }\end{array}$ \\
\hline $\begin{array}{l}\text { Крюденер А. А. } \\
\text { (Krjudener, 2003) }\end{array}$ & $\begin{array}{l}\text { «Сума всіх чинників, які дають нам поняття про відомий ліс, а саме: клімат, грунти, } \\
\text { інсоляція, які визначають склад насадження, умови відновлення і характер ведення } \\
\text { господарства» }\end{array}$ \\
\hline $\begin{array}{l}\text { Плугатар Ю. В. } \\
\text { (Рluhatar, 2014) }\end{array}$ & $\begin{array}{l}\text { «Об’єднує лісові ділянки, зайняті одним корінним типом деревостану, всіма похідними } \\
\text { від нього типами деревостану і асоціаціями, характеризується певними однорідними } \\
\text { умовами місцезростання і певним складом (асортиментом) порід, які беруть участь у } \\
\text { формуванні насадження» }\end{array}$ \\
\hline
\end{tabular}

5) історико-екологічні причини (Termena, 2004).

Вчений поділяє типи лісів на «основні», під якими розумів насадження з головних лісотвірних порід, які найбільше відповідають умовам місцезростання (наприклад, бори на піщаних грунтах) та «тимчасові» - це насадження із «порід-піонерів», або малоцінних порід, що виникли на місцях основних лісів. Проте вони існують недовго, тому що з часом їх знову витісняють головні лісотворні породи (Atrohin, 1988).

Морозовські погляди були сприйняті науковим колом не однозначно. Частина вчених підтримала його, частина критикувала. Одним з основних опонентів Г. Ф. Морозова був М. М. Орлов (Orlov, 1911), який вважав необов'язковим виділення типів лісу, а достатнім - орієнтуватися на головні характеристики лісових насаджень (продуктивність, клас бонітету тощо) (Migunova, 2009).

Академік Г. М. Висоцький (послідовник Г. Ф. Морозова) у своій праці «Про модернізовану типологію» (1912) дав відповідь М. М. Орлову, обгрунтувавши роль типології, адже клас бонітету не може мати переважного значення (Svyrydenko, 1995).

На основі вчення Г. Ф. Морозова виникло дві основні течії у подальшому розвитку лісової типології. Перший напрям розвивався на півночі Росії, де ліси були майже не змінені антропогенним впливом. Ця течія лісової типології була розвинута у працях В. М. Сукачова та його учнів. Інша течія виникла в Україні, де ліси зазнали значного впливу господарської діяльності. Цей напрям розвинувся у працях Є. В. Алексєєва, П. С. Погребняка, Д. В. Воробйова та інших (Atrohin, 1988).

Свою типологічну класифікацію лісів розробив А. А. Крюденер, який протягом багатьох років був учасником та організатором різноманітних робіт із дослідження лісів (Migunova, 2009). Він одним iз перших наголосив на необхідності розширення лісотипологічних досліджень. Також ученому належить одне 3 найбільш вдалих визначень терміна «тип насадження». Усі свої дослідження вчений будував на лісотипологічній основі.

А. А. Крюденер основою типу насадження вважав рослинне угрупування, що утворилося у даному кліматі за певних грунтових умов, яке без людського втручання має більш-менш константний характер. Учений назвав основні чинники, що визначають тип лісу: грунт, клімат і рослинне угрупування (Svyrydenko, 2004). У 1914 році (у праці «Таблица главных типов почвогрунтов и типичный почвенногрунтових условий»), вчений публікує свою класифікацію, яка вважається попередницею едафічної сітки Алексєєва - Погребняка (Svyrydenko, 1995). Класифікаційна таблиця А. А. Крюденера складалася із двох частин: 
1. Верхня частина (А). У ній виділено три групи земель, що відрізнялися ступенем та режимом зволоження: заболочені землі, заплави та суходоли. У цій же частині вказано типи грунтів за характером їх родючості (нейтральний,кислий перегній, торф) в залежності від умов зволоження і дренажу.

2. Нижня частина (В). У ній подано поділ грунтових умов за петрографічним складом і ступенем зволоженості (Migunova, 2009).

Отже, класифікація А. А. Крюденера мала вигляд двовимірної сітки, що відображає залежність зміни типів лісу від таких умов: 1) зволоженості (гідрометричні грунти); 2) механічного або петрографічного складу (до якого автор включає хімічну родючість, трофність); 3 ) клімату, шо визначає кліматичні типи лісових насаджень (Svyrydenko, 2004).

Так само, як Г. Ф. Морозов, учений виділяє типи лісів постійні і тимчасові (або перехідні). Назви визначеним типам лісів він дав, використовуючи народні найменування: сурамель, бір, субір, рамень (Svyrydenko, 1995).

Розроблена А. А. Крюденером типологічна класифікація лісів уперше була заснована на принципах районування території за основними кліматичними показниками, з наступним поділом кліматичних зон та областей на типи насаджень за особливостями петрографічного складу та водного режиму в різних зонах, виділених як географічні форми одного типу (Migunova, 2009).

Разом із тим класифікація Крюденера мала низку недоліків, яку згодом підмітив П. С. Погребняк: 1) нечіткість ознак якості перегною, аерації, сезонного зволоження; 2) дослідження грунтів до глибини лише 1 м і, як наслідок, помилковість твердження про прямолінійну залежність типів насадження та механічного складу грунтів; 3) А. А. Крюденер, досліджуючи насадження лісу та місцезростання у єдності, не визначив головного критерію цієї єдності (Svyrydenko, 2004).

Після смерті Г. Ф. Морозова та після переїзду А. А. Крюденера до Німеччини на початку XX століття посилилася позиція противників типологічного вчення, зокрема таких як М. М. Орлов. Тому подальший розвиток класифікації лісів дав не екологічний (морозовський), а ботанічний (Каяндера - Сукачова) принцип, який базувався на визначенні типів лісів на основі переважаючих у їх складі видів деревостану, майже не враховуючи умов місцезростання (Migunova, 2009).

Таким чином, розвитком типологічного вчення продовжили займатися фітоценологи, зокрема фінський ботанік та лісівник А. К. Каяндер (Каjander, 1933). Розвивалося його вчення ще одночасно 3 Морозовим Г. Ф. і навіть набуло популярності у окремих європейських країнах. Під типом лісу вчений розумів сукупність насаджень, які у дорослому і нормальному стані мають трав'янистий та моховий покрив відповідного складу, еколого-біологічного характеру. А. К. Каяндер поклав особливості живого надгрунтового покриву, а не грунтово-гідрологічні умови, в основу своєї класифікації. Він вважав, що однорідний надгрунтовий покрив - це хороший показник грунтових умов і що один і той самий покрив формується на біологічно повноцінних грунтах незалежно від їх механічного складу (Svyrydenko, 2004)

За характером пануючого надгрунтового покриву А. К. Каяндер дає назву типам лісу. Проте згодом, виділяючи типи лісів, учений починає враховувати деякі властивості грунтів (вологість, механічний склад, характер материнської породи), зрозумівши їх значущість.

Варто зазначити, що надгрунтовий покрив справді хороший індикатор лісорослинних умов, проте виділяти типи лісу лише на основі цього покриву не правильно. Типологічна класифікація А. К. Каяндера не набула широкого розповсюдження, оскільки ії не підтримували багато вчених (Svyrydenko, 1995).

Ботанічний підхід у виділенні типів лісу розвинув у своїх працях В. М. Сукачов (Sukachev, 1928). Учений, його колеги та учні ототожнювали тип лісу з рослинною асоціацією. Визначаючи типи лісу, основною ознакою вони вважали організацію фітоценозів (рослинних угрупувань), що виникла в результаті боротьби за існування між рослинами у співвідношенні з умовами середовища. В. М. Сукачову належить і вчення по біогеоценози, де він почав розглядати тип лісу як тип лісового біогеоценозу. Під біогеоценозом вчений розумів рослинне угрупування (фітоценоз), тваринний світ, що його населяє (зооценоз) і відповідну ділянку земної поверхні 3 особливими властивостями атмосфери (мікроклімату), геологічної будови, грунту і водного режиму, де все складає єдиний взаємозумовлений комплекс. Окрім того, В. М. Сукачов пропонує своє детальне визначення типу лісу. Коротко його можна розглядати як єдність умов і лісової рослинності, де рослинність найповніше відображає умови життя лісу (Atrohin, 1988).

В основу виділення типів лісу В. М. Сукачов кладе такі показники: вологість, родючість і характер зволоження грунту. Панівну деревну породу вчений 
вважав едифікатором для визначення типу лісу. Назви лісовим типам він давав подвійні - видові й родові (Svyrydenko, 2004).

В. М. Сукачов у своїх працях описав принципи, які він вважав необхідним покласти в основу майбутньої лісової типології, оскільки розроблення класифікації типів лісу - це робота майбутнього. Науковець зазначав, що побудовані ним ряди - лише приклад екологічних рядів, що складаються з рослинних угрупувань, які послідовно змінюють одне одного залежно від зміни умов місцезростання. Для прикладу вчений більш детально розробив типологію соснових і ялинових лісів у вигляді системи рядів (Svyrydenko, 1995).

В. М. Сукачов побудував свою схему у вигляді системи координат («хреста»). Верхня вісь, ряд А, являє собою ряд поступового збільшення сухості грунтів. На ліво від центру розміщений ряд В, тобто типи 3 поступовим наростанням застійного зволоження. Права вісь, ряд C, показує наростання родючості грунтів, а нижня вісь, ряд D - зростання проточного зволоження (Atrohin, 1988).

Слід зазначити, що В. М. Сукачов та його учні і послідовники внесли значний вклад у вивчення та дослідження лісів (Svyrydenko, 2004). Екологічний або морозовський напрям лісової типології отримав свій подальший розвиток на теренах України у працях Є. В. Алексєєва, П. С. Погребняка, Д. В. Воробйова та інших.

Основоположником української школи лісової типології вважається Є. В. Алексєєв. У своїй праці «Типы насаждений, их отношение к бонитетам и хозяйственным классам при лесоустройстве», надрукований 1915 року в «Лесном журнале», вчений звернув увагу на необхідність вивчення бонітетів як одну з найважливіших ознак, що поряд з іншими властивостями лісів повинна лежати в основі лісової типології (Svyrydenko, 1995).

Цікавим фактом є те, що Є. В. Алексєєв у своїх дослідженнях опирався на праці А. А. Крюденера, проте через негативне ставлення, що склалося до останнього після його еміграції, Алексєєв мало посилався на нього, використавши його класифікацію як загальноприйняту, лише дещо змінивши та уточнивши їі згідно з особливостями свого регіону (Migunova, 2009).

Свою класифікацію Алексєєв заснував на умовах місцезростання, зокрема, на основі таких ознак: клімат, рельєф та грунтові умови. Серед перелічених елементів найбільше значення надається грунтовим умовам, адже клімат та рівнинний рельєф є малозмінними. Під «типом насадження» вчений розумів сукупність однорідних насаджень, об'єднаних загальним походженням, формою і складом. А під «типом лісу» (або «типом лісової ділянки») - сукупність однорідних ділянок лісу, об'єднаних сукупністю умов місцеоселення (Svyrydenko, 2004).

Класифікація С. В. Алексєєва (1925) представлена у вигляді двовимірної сітки - «по суходолу» i «по мокрому». На першій осі розміщені групи за родючістю грунтів - від пісків (бори) до суглинків (груди) і чорноземів (діброви). На другій - групи вологості «по суходолу» (найсухіші, сухі, свіжі, вологі, сирі) і «по мокрому» - вільшаники і багни (мохові болота) (Migunova, 2009).

Разом із тим типологічна класифікація С. В. Алексєєва має свої недоліки, пов' язані з відсутністю в автора чіткої методики: 1) діброви не пов'язані із судібровами; 2) немає відповідності між дібровами та грудами на чорноземах; 3) глибина залягання грунтових вод відповідає лише двом типам - борам та суборам; 4) непослідовність у теоретичних позиціях (Svyrydenko, 1995).

Розвиток екологічного напряму лісової типологічної класифікації пов'язаний 3 іменем Г. М. Висоцького, який у 1926 - 1929 рр. організував типологічну експедицію з метою вивчення українських лісів. У дослідженні взяли участь такі вчені: П. С. Погребняк (як грунтознавець), Д. В. Воробйов та П. П. Кожевніков (у ролі геоботаніків), В. Е. Шмідт (як лісівник). Експедиція займалася вивченням лісів Полісся та Лісостепу (Herushynskyi, 1996).

Основним результатом роботи експедиції і основною заслугою, зокрема, П. С. Погребняка було створення доволі досконалої класифікаційної моделі типів лісу - едафічної сітки (рис.) (Migunova, 2009).

Вчений удосконалив класифікацію Є. В. Алексєєва та в результаті своєї роботи отримав чітку класифікаційну схему за трофністю (хімічною родючістю) і вологістю грунтів. П. С. Погребняк вводить індекси для позначення груп лісових грунтів: A - бори (дуже бідні грунти), В - субори (відносно бідні), C - складні субори (відносно багаті), D - груди на сірих лісових грунтах, E - діброви на чорноземах. Разом із тим за показником вологості виділяються гігротопи, яким даються цифрові позначення: 1 - сухі, 2 - свіжі, 3 - вологі, 4 - сирі, 5 - мокрі (Svyrydenko, 2004).

П. С. Погребняк виділяв провідні фактори, що зумовлюють різноманітність природних лісів, їх склад та продуктивність: світло, вологу, тепло, мінеральні поживні речовини у грунтах. Тобто це найважливіші чинники неорганічного середовища (Herushynskyi, 1996). 


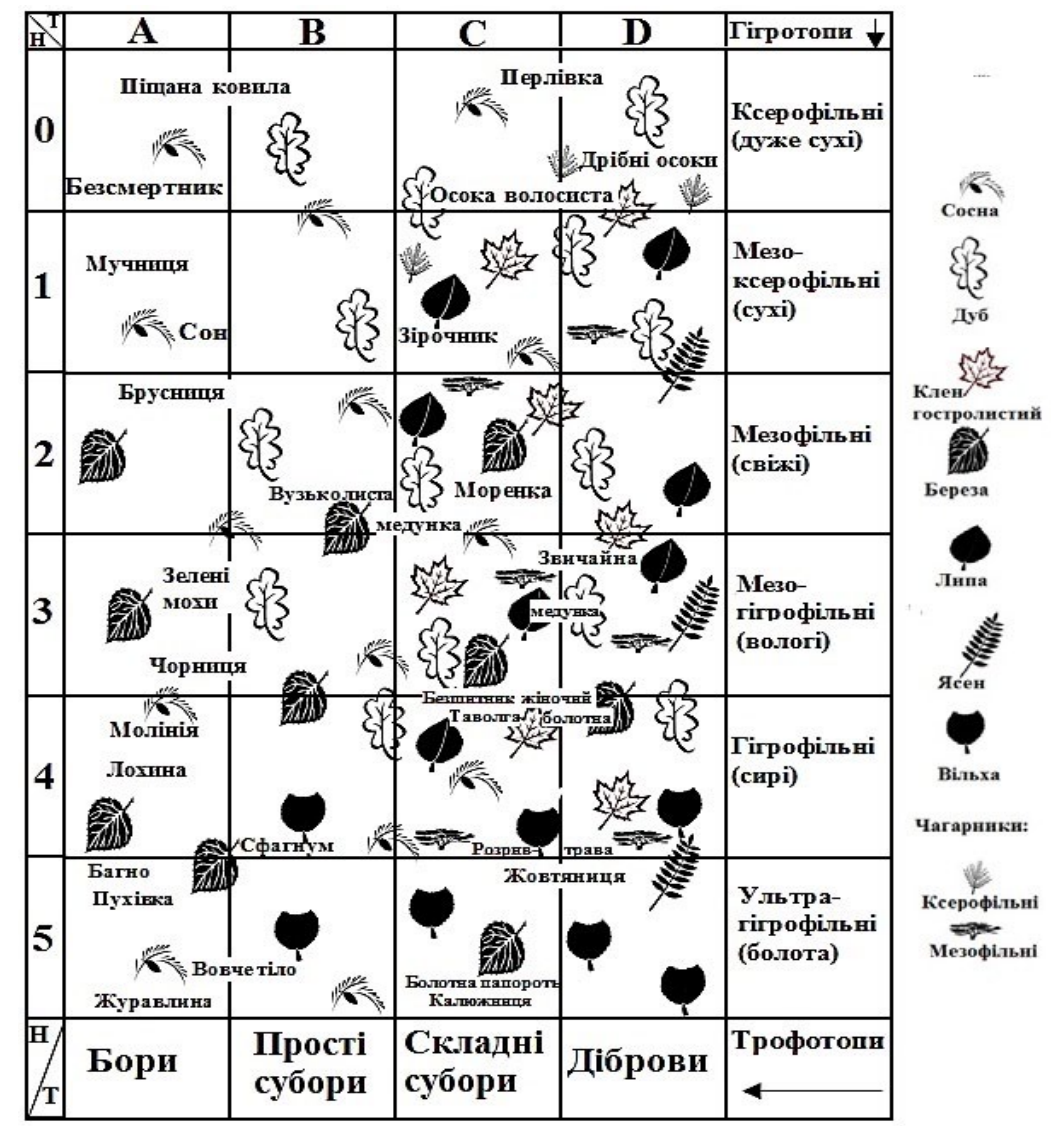

Рис. Едафічна сітка Алексєєва - Погребняка (Kanskyi, 2014).

Окрім цього вчений виділив ознаки, що визначають тип лісорослинних умов: деревна порода, iii ріст, рівень грунтових вод, склад надгрунтового покриву. Результатом подальших досліджень стало вдосконалення едафічної сітки. Зокрема, діброви на чорноземах були приєднані до групи $\mathrm{D}$, а також було введено новий індекс - 0 , для того, щоб визначити вкрай сухі лісорослинні умови (рис.) (Svyrydenko, 2004).

Суть цієї класифікації полягає у тому, що кожна лісова ділянка розглядається одночасно і як трофотоп, і як гігротоп, тобто із двох сторін одного й того ж місцезростання - едатопу. В результаті проведених робіт, змін і удосконалень остаточно була створена сучасна едафічна сітка для типологічної класифікації лісів, яка отримала назву на честь двох вчених «Алексєєва - Погребняка».

Типи лісу згідно з цією класифікацією отримують назву за трофністю і за вологістю грунтів (наприклад, сухий бір, вологий субір, свіжа діброва тощо) та позначаються буквами й цифрами, наприклад, вищезгадані типи - $\mathrm{A}_{1}, \mathrm{~B}_{3}$ i $\mathrm{D}_{2}$ (Atrohin, 1988).

Д. В. Воробйов під типом лісової ділянки (едатопом) розумів географічно, кліматично, аерогенетично розміщені типи лісів, подібні за родючість грунтів.
Вчений також зазначав, що в різних географічних районах умови місцеоселення можуть бути подібними, але ці ділянки будуть зайняті іншими породами, а відтак належатимуть до інших лісових типів.

Тому у своїй класифікації Д. В. Воробйов урахував залежність між типологічними одиницями лісу і кліматом, наголошуючи, що якщо тип лісової ділянки сформувався на однотипному рельєфі та на однотипних грунтових породах, визначальну роль матиме розподіл тепла і вологи. Також тип лісу пов'язаний із зміною континентальності клімату, а продуктивність деревостану прямо пропорційна кількості тепла (Pluhatar, 2014).

Разом із класифікацією едафічних умов Д. В. Воробйов розробив класифікацію кліматів як складову частинку у типології лісів. Вчений розробляє кліматичну сітку, в основу якої кладе такий принцип: «Чим клімат вологіший і холодніший, тим типи вологіші і бідніші; і навпаки: чим клімат сухіший і тепліший, тим типи сухіші і багатші» (Vorobjov, 1953).

Д. В. Воробйов виокремлює такі кліматичні показники, що найбільше визначають взаємозв'язок типів лісу та клімату:

1) сума позитивних місячних температур (T); 
2) показник вологості клімату ( $\mathrm{W}=\mathrm{R} / \mathrm{T}-0,026 \mathrm{~T})$, де $\mathrm{R}$ - сума опадів за теплий період;

3) показник континентальності клімату (А), який визначається як різниця між температурою найтеплішого та найхолоднішого місяців.

Урахування середніх місячних показників тепла, вологи та континентальності клімату дає можливість доволі чітко охарактеризувати кліматичні умови, які визначають особливості формування відповідного типу лісу (Vorobjov, 1953).

Шляхом поєднання кліматичної та едафічної сіток одержано класифікаційну едафо-кліматичну сітку Погребняка - Воробйова (табл. 2). Вона відображає комплексний результат впливу на утворення та формування типів лісу трьох найважливіших показників середовища - кліматичних (тепла та вологи), едафічних - трофності грунту.

Слід зазначити, що українські вчені Є. В. Алексєєв, П. П. Кожевніков, П. С. Погребняк, Д. В. Воробйов звернули увагу на взаємозалежність типів лісу від місцезростання деревостану, але вони занадто переоцінили рось середовища у лісовій типології (Kanskyi, 2014).

Такий підхід яскраво підтверджують праці П. П. Кожевнікова, в яких він об'єднує в один і той же тип ліси і натуральні, і антропогенні: «В условиях одного и того же типа лесорастительных условий могут быть типы леса как естественной растительности (коренной тип и ряд производных), так и искусственно созданной (культуры).
Сюда же относятся возникшие после вырубки леса лесосеки, пустыри, прогалины в лесу» (Kozhevnykov, 1931).

Першу спробу виділити географічні екотопи зробив М. М. Вересін під час вивчення дібров. Вчений помилково назвав екотопи формами, а також запропонував виділяти ще й екотипи. Виділення останніх було більш вдалим, тому що вони тісніше пов'язані з умовами місцеоселення, ніж так звані форми. Класифікація М. М. Вересіна була доволі детальною, бо описувала велику різноманітність дібров. Недоліком його роботи було неврахування місцевих відмінностей дубових лісів (Kanskyi, 2014).

Розвинув та удосконалив ідеї М. М. Вересіна В.І.Білоус, який у своїх дослідженнях більше враховував типи місцевостей, експозиції схилів тощо. Висновки. У вищезазначених та інших працях із типології та класифікації лісів здебільшого розглядаються загальні питання щодо лісових ландшафтів. На сучасному етапі розвитку географічної науки у вивченні лісової типології застосовуються нові методи дослідження, одним із яких є метод математичного моделювання, котрий дає можливість прогнозувати майбутній стан лісів (Termena, 2004). Отже, розвиток лісотипологічної науки в сучасних умовах є актуальним, проте потребує глибшого вивчення, удосконалення та модернізації методів дослідження та впровадження досягнутих результатів у лісокористування для збереження лісових ресурсів та для їх раціонального використання.

Таблиия 2

Едафо-кліматична сітка Погребняка - Воробйова

\begin{tabular}{|c|c|c|c|c|c|c|c|c|}
\hline \multirow{2}{*}{\multicolumn{2}{|c|}{$\begin{array}{c}\text { Едатопи } \\
\text { a } \\
\end{array}$}} & \multicolumn{4}{|c|}{ Трофотопи } & \multirow{2}{*}{\multicolumn{3}{|c|}{ W }} \\
\hline & & b & c & d & & & & \\
\hline \multirow{5}{*}{ 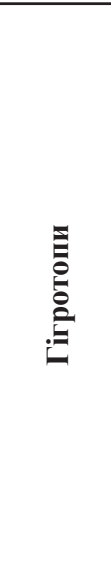 } & 1 & $\mathrm{~A}_{1}$ & $\mathrm{~B}_{1}$ & $\mathrm{C}_{1}$ & $\mathrm{D}_{1}$ & $\begin{array}{r}-0,8 \\
0,6\end{array}$ & 1 & \multirow{5}{*}{ 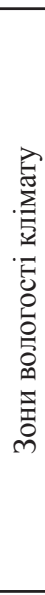 } \\
\hline & 2 & $\mathrm{~A}_{2}$ & $\mathrm{~B}_{2}$ & $\mathrm{C}_{2}$ & $\mathrm{D}_{2}$ & 2,0 & 2 & \\
\hline & 3 & $\mathrm{~A}_{3}$ & $\mathrm{~B}_{3}$ & $\mathrm{C}_{3}$ & $\mathrm{D}_{3}$ & 3,4 & 3 & \\
\hline & 4 & $\mathrm{~A}_{4}$ & $\mathrm{~B}_{4}$ & $4 \mathrm{c}$ & $\mathrm{D}_{4}$ & 4,8 & 4 & \\
\hline & 5 & $\mathrm{~A}_{5}$ & $\mathrm{~B}_{5}$ & $\mathrm{C}_{5}$ & $\mathrm{D}_{5}$ & 6,2 & 5 & \\
\hline \multirow[t]{3}{*}{$\mathbf{T}\left({ }^{\circ} \mathbf{C}\right)$} & & 44 & 61 & 84 & 104 & \multirow{3}{*}{\multicolumn{3}{|c|}{ Кліматопи }} \\
\hline & a & b & c & d & & & & \\
\hline & & Тепло & ві зони & & & & & \\
\hline
\end{tabular}




\section{Бібліографічні посилання}

Alekseev E. V., 1927. Ob osnovnyh ponjatijah lesovodstvennoj tipologii. [About the fundamental ideas of forest typology]. Nauka, Kiev (in Ukrainian).

Atrohin V. G., 1988. Lesnaja hrestomatija [Wood chrestomathy]. Lesn. prom.-st., Moskva (in Russian).

Baron Krjudener, 1916. Osnovy klassifikacii nasazhdenij i ih narodohozjajstvennoe znachenie $\mathrm{v}$ obihode strany [Basics classification of plants and their economic importance in the everyday life of the country]. Tipogr. glavn. upr. udelov, Petrograd (in Russian).

Belgard A. L., 1950. Lesnaja rastitelnost jugo-vostoka USSR [Forest vegetation of southeast of the Ukrainian SSR]. Izd-vo Harkov. Gosudar. Univer, Harkov (in Russian).

Bilous V. I., 1994. Selektsiia ta nasinnytstvo duba. [Selection and Seed of Oak]. AN Vyshch. Shkoly Ukrainy, Cherkasy (in Ukrainian).

Genko N. K., 1902. Harakteristika Belovezhskoj pushhi i istoricheskie o nej dannye [Characteristics of the Bialowieza Forest and the historical data on it]. Lesnoj zhurnal, 5, 1012-1056 (in Russian).

Gutorovich I. I., 1908. O tipah nasazhdenij voobshhe i Agafonskoj dachi Lifljandskoj gub. v chastnosti [About the types of plants in general and of Agafonska dachas in Livonia in particular]. Lesnoj zhurnal, 10, 1253-1276 (in Russian).

Herushynskyi Z. Yu., 1996. Typolohiia lisiv Ukrainskykh Karpat: Navchalnyi posibnyk ] - L.: vyd-vo "Piramida" (in Ukrainian).

Holubets M. A., 2000. Ekosystemolohiia. [Ecological systemology]. Polli, Lviv (in Ukrainian).

Kajander A. K., 1933. Sushhnost i znachenie tipov lesa. [The essence and importance of forest types]. Goslestehizdat, Moskva (in Russian).

Kanskyi V. S., 2014. Analiz rozvytku doslidzhen typolohii lisovykh landshaftiv Ukrainy [Analysis of forest landscape research typologies of Ukraine]. Naukovi zapysky Vinnytskoho derzhavnoho pedahohichnoho universytetu imeni Mykhaila Kotsiubynskoho. Seriia: Heohrafiia. 26, 108-112 (in Ukrainian).

Kravchinskij D. M., 1883. Lesovozrashhenie. Osnovanija lesohozjajstvennogo rastenievodstva. [Reforestation. Bases of agricultural plant growing]. Devrien, SanktPeterburg (in Russian).

Krjudener A.A., 2003. Osnovy klassifikacii tipov nasazhdenij [Basics of classification types of plantations]. MGUL, Moskva (in Russian).

Kolesnikov B.P., 1958. Sostojanie sovetskoj lesnoj tipologii i problemy geneticheskoj klassifikacii tipov lesov [Status of the Soviet forest typology and problems of genetic classification of forest types]. Izv. SO AN SSSR., 2, 107-122 (in Russian).

Korzhinskij S. I., 1886. Nekotorye dannye otnositelno severnoj granicy chernozemnoj oblasti v vostochnoj polose
Evropejskoj Rossii. [Some data about the northern boundary of the chernozem region in the eastern zone of European Russia]. Prilozhenie k protokolu zasedanija o-va estestvoispytatelej pri Kazan. Un-te. 87, 1-5 (in Russian).

Kozhevnykov P. P., 1931. Typy lisu ta lisovoi asotsiatsii Podillia. [Forest types and forest associations of Podillya]. Lisoroslynni umovy Podillia, Kharkiv (in Ukrainian).

Migunova E. S., 2009. Lesnaja tipologija, shkola V. V. Dokuchaeva i voprosy geografyi. [Forest typology, school of Dokuchaev and geography questions]. Novoe slovo, Harkov (in Ukrainian).

Morozov G. F., 1904. O tipah nasazhdenij i ih znachenii v lesovodstve [About the types of plants and their role in forestry]. Lesnoj zhurnal. 1, 6-25 (in Russian).

Morozov G. F., 1949. Uchenie o lese. [The doctrine of the forest]. Goslesbumizdat, Moskva-Leningrad (in Russian).

Orlov M. M., 1911. Sudba ponjatija «tip nasazhdenija» V russkoj lesnoj literature. [The fate of the concept of «type of plantings» in the Russian forestry literature]. Lesopromyshlennyj vestnik. 50, 553-556 (in Russian).

Pluhatar Yu. V., 2014. Ekologichne lisoznavstvo [Ecological forest science]. FOP Hrin D. S., Kherson (in Ukrainian).

Pogrebnjak P.S., 1955. Osnovy lesnoj tipologii. [Fundamentals of forest typology]. Izd-vo AN USSR, Kiev (in Russian).

Rudzkij A., 1906. Rukovodstvo k ustrojstvu russkih lesov. [Guide to the device of Russian forests]. Sankt-Peterburg (in Russian).

Serebrennikov P. P., 1904. Tipy nasazhdenij Vershinskoj dachi. [The types of plants of Vershinskaya dachas]. Lesnoj zhurnal. 1, 69-93. 2, 341-380 (in Russian).

Sukachev V. N., 1928. O nekotoryh osnovnyh voprosah tipologii lesa. [About some basic issues of forest typology]. Lesnoe hazjajstvo. 3, 36-41 (in Russian).

Sukachjov V. N., 1972. Osnovy lesnoj tipologii i biogeocenologii [Basics of forest typology and biogeocenology]. Nauka, Leningrad (in Russian).

Svyrydenko V. Ye., 2004. Lisivnytstvo. [Forestry]. Aristei, Kyiv (in Ukrainian).

Svyrydenko V. Ye., 1995. Lisivnytstvo. [Forestry]. Silhosposvita, Kyiv (in Ukrainian).

Termena B. K., 2004. Lisoznavstvo z osnovamy lisivnytstva. [Forestry with basics of silviculture]. Lesn. prom.-st., Moskva (in Russian).

Veresin M. M., 1971. Lesa Voronezhskie. [Forests of Voronezh]. C-Ch kn. izd., Voronezh (in Russian).

Vorobev D. V., 1953. Tipy lesov Evropejskoj chasti SSSR. [Types of forests in European part of the USSR]. Izd-vo AN Ukrainskoj SSR, Kiev (in Russian).

Vysockij G. N., 1960. Izbrannye Trudy. [Selected works]. Selhozgiz, Moskva (in Russian).

Надійшла до редколегії 26.02.2016 